University of Nebraska - Lincoln

DigitalCommons@University of Nebraska - Lincoln

4-1-2006

\title{
Foreign Direct Investment and Economic Growth: A Time-Series Approach
}

Atrayee Ghosh Roy

Minnesota State University, Mankato, atrayee.ghosh-roy@msus.edu

Hendrik F. Van den Berg

University of Nebraska-Lincoln, hvan-den-berg1@unl.edu

Follow this and additional works at: https://digitalcommons.unl.edu/econfacpub

Part of the Economics Commons

Ghosh Roy, Atrayee and Van den Berg, Hendrik F., "Foreign Direct Investment and Economic Growth: A Time-Series Approach" (2006). Economics Department Faculty Publications. 32.

https://digitalcommons.unl.edu/econfacpub/32

This Article is brought to you for free and open access by the Economics Department at DigitalCommons@University of Nebraska - Lincoln. It has been accepted for inclusion in Economics Department Faculty Publications by an authorized administrator of DigitalCommons@University of Nebraska - Lincoln. 


\title{
Global Economy Journal
}

Volume 6, Issue 1

2006

Article 7

\section{Foreign Direct Investment and Economic Growth: A Time-Series Approach}

\author{
Atrayee Ghosh Roy* Hendrik F. Van den $\operatorname{Berg}^{\dagger}$
}

*Minnesota State University, Mankato, atrayee.ghosh-roy @mnsu.edu

†University of Nebraska-Lincoln, hvan-den-berg1@unl.edu

Copyright (c)2006 The Berkeley Electronic Press. All rights reserved. 


\title{
Foreign Direct Investment and Economic Growth: A Time-Series Approach
}

\author{
Atrayee Ghosh Roy and Hendrik F. Van den Berg
}

\begin{abstract}
Research has often focused on how foreign direct investment (FDI) transfers technology from developed economies to less developed economies. Most FDI occurs between developed economies, however, and the country receiving the greatest inflow of FDI is the United States. This paper examines whether such FDI inflows have stimulated growth of the U.S. economy. We apply time-series data to a simultaneous-equation model (SEM) that explicitly captures the bi-directional relationship between FDI and U.S. economic growth. FDI is found to have a significant, positive, and economically important impact on U.S. growth. Also, our SEM estimates reveal that FDI growth is income inelastic. These results imply that: (1) even a technologically advanced country such as the U.S. benefits from FDI, (2) the gains from FDI are very substantial in the long run, and (3) the sustainability of the U.S. current account deficit is enhanced by FDI's positive effect on productivity but undermined by the income inelasticity of FDI. Overall, the results suggest that U.S. policies should focus on keeping the country attractive to foreign direct investors.
\end{abstract}

KEYWORDS: foreign direct investment, economic growth, globalization, simultaneity, stationary 
Ghosh Roy and Van den Berg: Foreign Direct Investment and Economic Growth

\section{INTRODUCTION}

The debate over the merits of globalization cannot be settled until we gain a firm understanding of how globalization affects human welfare. Since long-run human welfare depends on economic growth, we must get a better handle on globalization's effects on economic growth. Globalization covers a wide array of economic activities, including international trade, international migration, and international investment. An accurate assessment of whether globalization is good for economic growth requires that we examine the growth effects of all of the components of globalization. Not all these components have been studied thoroughly, and empirical evidence suggests that each of the activities that make up globalization may have very different growth effects.

There is a large literature on international trade's effects on economic growth. Detailed in surveys of the literature by Edwards (1993, 1998), Baldwin (2003), and Lewer and Van den Berg (2003) suggest that there is a broad consensus that trade is good for economic growth. These surveys do point out some econometric shortcomings of the studies, and there are some lingering doubts about the exact size and importance of the trade-growth relationship. Rodriquez and Rodrik (2001) and Rodrik, Subramnian, and Trebbi (2002) show that omitted institutional variables may have exaggerated trade's strong showing in many empirical growth regressions. Nevertheless, the wide range of empirical studies that find a positive correlation between trade and growth, combined with the lack of any evidence that would suggest that trade hinders economic growth, has led most economists to accept that, ceteris paribus, international trade is good for growth.

Such a consensus has not yet been reached in the cases of international migration and international investment, however. There has been little systematic research on the growth effects of immigration, which represents a serious shortcoming of economic research. The growth effects of international investment have been more widely studied, but the evidence accumulated so far is much less clear than the evidence on the relationship between international trade and economic growth.

Economic theory suggests that international investment results in a more efficient allocation of world savings, more intertemporal consumption smoothing, and more risk reduction through asset diversification. International investment has also been linked to international technology transfers. Eaton and Kortum (1996), Conolly (1997), Coe and Helpman (1995), Coe, Helpman, and Hoffmaister (1997), and Bernstein (1996) showed that foreign countries are the principal source of new technologies for all but the very largest economies, such as the United States. Theory and evidence thus seems to suggest that international investment is good for economic growth. 
Among the different categories of international investment, foreign direct investment (FDI) is most often distinguished for its role in transferring technology. Caves (1996) and Balasubramanyam, Salisu, and Sapsford (1996) found that foreign direct investment (FDI) is the form of international investment most likely to drive international technology diffusion. Moran (1998) reflects a large segment of the literature when he describes FDI's growth effects:

Local subsidiaries exhibit an integration effect when they become part of the parents' strategy to maintain a competitive position in world markets that provides more rapid upgrading of management, technology, and quality control than any other form of transfer. Thus, they create a dynamic link to the global frontier of best practices; most advanced technologies, and most sophisticated operational techniques in an industry. Simultaneously, they generate direct and indirect spillovers and externalities for domestic suppliers. FDI that creates a proprietary network of suppliers introduces a powerful interaction between parents and subsidiaries and between subsidiaries and host countries. ${ }^{1}$

Romer (1993) emphasized FDI's role in diffusing technology and its relationship to economic growth: "...for the poorest developing nations, letting multinational firms profit from the international transmission of ideas is the quickest and most reliable way to reduce the idea gaps that keep them poor."2 More fundamentally, FDI's potential role in the growth process as a diffuser of technology is supported by Solow's (1956) growth model and Easterly and Levine (2001) and Caselli's (2004) empirical evidence, which show that long term economic growth is driven by technological progress and not just factor accumulation.

Not all empirical evidence supports the hypothesis that FDI plays a positive role in diffusing technology and stimulating economic growth, however. Haddad and Harrison (1993) studied Morocco, Aitken and Harrison (1999) studied Venezuela, Djankov and Hoekman (2000) analyzed data for the Czech Republic, and Konings (2001) examined Poland and Bulgaria, and all these studies failed to find technology spillovers from FDI. Rodrik (1999) wrote that: "today's policy literature is filled with extravagant claims about positive spillovers from FDI but the evidence is sobering."

\footnotetext{
${ }^{1}$ Theodore H. Moran (1998), Foreign Direct Investment and Development, Washington, D.C.: Institute for International Economics, p. 158.

${ }^{2}$ Paul Romer (1993), "Idea Gaps and Object Gaps in Economic Development," Journal of Monetary Economics, Vol. 32, p. 548.
} 
Many studies have found that technological progress tends to be concentrated in certain geographic areas and move between countries only sluggishly. Glaeser et al. (1991) remind us that "...intellectual breakthroughs must cross hallways and streets more easily than oceans and continents.", Abramovitz (1986) pointed out that the potential for technology to move across a border and spillover from FDI to the rest of the economy also depends on whether a country's "social capability" is adequate to absorb more advanced technologies." "Abramovitz' conclusions have been confirmed by Evenson and Singh (1997), Borenztein, De Gregorio, and Lee (1998), Aitken and Harrison (1999), Branstetter (2000), and Mayer (2001). Keller (1996) has built an interesting model in which the growth of technology inflows approaches the rate of growth of human capital in the recipient country, not the rate of technological progress abroad.

Human capital is not the only determinant of countries' varying capacities for absorbing technology. Balasubramanyam, Salisu, and Sapsford (1996) found that the size of FDI's technology spillovers depends critically on whether domestic firms are protected from import competition. Pattillo, Poirson, and Ricci (2002) found that macroeconomic stability is critical to attracting FDI. Smarzynska (2000) presented evidence suggesting that firms with leading technologies prefer wholly-owned overseas subsidiaries to joint ventures; she therefore concluded that regulations on foreign ownership shares affect technology transfers. Basu and Weil (1998) and Acemoglu and Zilibotti (2001) have investigated the "appropriateness" of developed country technology for developing economies.

Another factor complicating the issue is the fact that FDI is not the only channel through which knowledge flows between countries. International technology transfers occur for a variety of reasons. Keller $(2001,2002)$ found that trade patterns statistically explain well over half of the differences in bilateral technology diffusion among developed economies, while FDI explains only about 15 percent of the bilateral variation. On the other hand, Hajeazi and Safarian (1999) used different data and methods to reach the conclusion that FDI accounts for a greater portion of technology flows between OECD countries than does trade.

These, and many other, studies make it very clear that the relationship between FDI and economic growth is complex. Given that we are not yet certain about the growth effects of one specific form of international investment like FDI,

\footnotetext{
${ }^{3}$ Edward Glaeser, H. D. Kallal, José Scheinkman, and Andre Schleifer (1991).

${ }^{4}$ Moses Abramovitz (1986), "Catching Up, Forging Ahead, and Falling Behind," Journal of Economic History, Vol. 46(2), (pp. 385-406).p. 405.
} 
the lack of a consensus on international investment's general role in the process of economic growth is not surprising.

\section{FINDING THE GROWTH EFFECTS OF FDI}

The uncertainty surrounding the relationship between economic growth and international investment in general, and FDI in particular, may be partly due to econometric problems. For one thing, statistical analysis is hampered by the scarcity of long-run data. While multinational firms have been expanding their share of the world production for over a century, the huge volume of foreign direct investment that we observe today is really a phenomenon of the past two decades. Also complicating the econometric studies is the difficulty of disentangling international investment from the many factors that determine an economy's rate of growth. FDI is most likely both a cause and a consequence of technological progress in a country. Thus, regression estimates of FDI's effect on economic growth will be subject to omitted variable bias and simultaneity bias. Some recent studies have added explanatory variables and instrumental variables to overcome these difficulties.

Discussions of FDI's role in transferring technology usually focus on developing economies. However, the largest FDI flows occur between developed economies. That is, countries that are already at or near the cutting edge of technological development receive the most FDI from other countries at or near the cutting edge. There is evidence to suggest that developed countries at the cutting edge of technological progress may not benefit from foreign investment to the same degree as developing economies. Coe and Helpman (1995) examined how R\&D activity affects total factor productivity (TFP) at home and abroad in 22 developed countries; their results show that in large developed countries' TFP benefits more from domestic R\&D activity than foreign R\&D activity. Bernstein (1996) examined R\&D and TFP across a broad sample of Canadian and U.S. industries; he found that in Canada the effect of foreign R\&D activity was greater than the effect of domestic R\&D, but in the U.S. domestic R\&D activity accounted for a much greater share of TFP gains than foreign R\&D. According to Bernstein and Mohnen (1998), U.S. R\&D activity explains 60 percent of Japan's total factor productivity growth, and Japanese R\&D activity accounts for 20 percent of the U.S.'s productivity gains. Only a few studies have focused specifically on FDI in developed countries. For example, Haskel et al. (2002) reported positive spillovers from FDI to the rest of the British economy, and Keller and Yeaple (2003) reached the same conclusion for the U.S. economy. 
Ghosh Roy and Van den Berg: Foreign Direct Investment and Economic Growth

\section{FDI AND THE UNITED STATES ECONOMY}

The United States, clearly the world's technology leader, has in recent years been the country that received the greatest inflows of FDI. The United States attracts large inflows of FDI because it offers favorable conditions for multinational firms to operate profitably. The United States does not restrict foreign investment, foreign-owned firms are treated on an equal basis to domestic firms, its labor force is highly educated, the U.S. market is very large, and macroeconomic policies have maintained a steady macroeconomic environment over the past twenty years. Evidence reported earlier suggests a country's capacity to "absorb" foreign technology determines the extent of technology transfers. Thus, a developed country such as the United States is likely to benefit greatly from FDI inflows. On the other hand, as a technology leader the United States may gain less new technology from FDI than countries that are still far from the cutting edge of technology. Recall the evidence referenced above showing that U.S. technological progress has not been very much influenced by inflows of foreign technology. The question of whether the United States' rate of technological progress is accelerated by FDI is therefore difficult to determine a

priori. Further empirical analysis is clearly called for.

The growth effects of foreign investment in the United States are an interesting research topic for two further reasons. First, the United States has been open to foreign investment longer than most countries and thus provides longer time-series data for examining the growth effects of FDI than are available from most other countries. Furthermore, the U.S. has been running huge and growing current account deficits that have been financed by equally large investment inflows. Whether the growing U.S. trade deficit is sustainable hinges, in part, on whether investment inflows enhance U.S. productivity.

The question of whether the United States gained from the large inflows of foreign direct investment is therefore both relevant and important for understanding the growth effects of international investment. This paper provides empirical evidence to help us answer this question.

\section{MODELING THE RELATIONSHIP BETWEEN FDI AND ECONOMIC GROWTH}

In order to test the importance of foreign direct investment for economic growth, we specify a version of the familiar sources of growth equation:

$$
\operatorname{Gr}(\mathrm{Y})=\mathrm{a}_{\mathrm{o}}+\mathrm{a}_{1} \operatorname{Gr}(\mathrm{K})+\mathrm{a}_{2} \operatorname{Gr}\left(\mathrm{K}_{\mathrm{FDI}}\right)+\mathrm{a}_{3} \operatorname{Gr}(\mathrm{L})+\mathrm{a}_{4} \mathrm{Gr}(\mathrm{X})
$$


The variables $\operatorname{Gr}(\mathrm{Y}), \operatorname{Gr}(\mathrm{K}), \operatorname{Gr}\left(\mathrm{K}_{\mathrm{FDI}}\right), \mathrm{Gr}(\mathrm{L})$, and $\operatorname{Gr}(\mathrm{X})$ are growth rates of real gross domestic product, the total capital stock minus accumulated FDI, accumulated FDI, the labor force, and exports, respectively. Model (1) is similar to the well-known sources of growth equation derived from a neoclassical production function. For example, suppose the neoclassical production function is of the Cobb-Douglas form

$\mathrm{Y}=\mathrm{AK}^{\alpha} \mathrm{L}^{1-\alpha}$

where $\mathrm{Y}, \mathrm{K}$ and $\mathrm{L}$ are real gross domestic product, capital stock and labor, respectively. $\mathrm{A}$ is a parameter that measures total factor productivity, and $\alpha$ and $1-\alpha$ are the relative shares of capital and labor. Converting equation (1) into log linear form yields,

$\dot{\mathrm{Y}}=\dot{\mathrm{A}}+\alpha \dot{\mathrm{K}}+(1-\alpha) \dot{\mathrm{L}}$

where $\dot{\mathrm{Y}}, \dot{\mathrm{A}}, \dot{\mathrm{K}}$ and $\dot{\mathrm{L}}$ are growth rates of real gross domestic product, total factor productivity, capital and labor, respectively. Our specification resembles equation (3) except that we split the capital stock into accumulated FDI and all other capital and also add a trade variable, the growth rate of real exports. Such a split has been used by Most and Van den Berg (1996) to examine whether the source of investment financing matters in developing economies. Equation (1) also adds the growth rate of real exports, $\operatorname{Gr}(\mathrm{X})$, to the equation to reflect the influence of international trade on economic growth. Since both international trade and investment have grown rapidly over the past several decades, the coefficient of $\mathrm{Gr}\left(\mathrm{K}_{\mathrm{FDI}}\right)$ would very likely be biased if international trade were omitted from the equation.

We follow the common practice of substituting the ratio of investment to GDP for the growth rate of the capital stock. Econometrically, this changes the estimated value of the regression coefficient but, given the way capital stock estimates are normally computed, it does not imply any loss of information or distortion of the significance of the relationship. There is seldom data on actual capital stocks, and most time-series of capital stocks are estimates derived by the perpetual inventory method. This method uses annual investment data and adjusts the accumulated investment by an assumed rate of depreciation. Therefore, in these time-series the variation in the capital stock is driven entirely by annual investment from the national accounts, precisely the same investment in the numerator of $\mathrm{I} / \mathrm{Y}$. The investment ratio can conveniently be split into the ratio of total investment minus FDI to GDP, which we denote simply as I/Y, and FDI/Y. 
These ratios replace $\mathrm{Gr}(\mathrm{K})$ and $\mathrm{Gr}\left(\mathrm{K}_{\mathrm{FDI}}\right)$ in equation (1). We thus specify the following estimation equation:

$\operatorname{Gr}(Y)=a_{o}+a_{1}(I / Y)+a_{2}(F D I / Y)+a_{3} \operatorname{Gr}(L)+a_{4} \operatorname{Gr}(X)$

In this study, we are particularly interested in the value and statistical significance of $\mathrm{a}_{2}$.

Estimates of the coefficients in model (4) are likely to be biased. Specifically, the relationships between $\operatorname{Gr}(\mathrm{Y})$ and FDI/Y and between $\operatorname{Gr}(\mathrm{Y})$ and $\operatorname{Gr}(\mathrm{X})$ are probably bi-directional. We are interested in testing the hypothesis that FDI/Y has a positive effect on $\operatorname{Gr}(Y)$, but it is equally likely that a growing economy attracts more foreign capital than a stagnant or slow growing economy. This is no doubt one of the reasons why a disproportionate share of world FDI occurs among the most developed economies and a select group of relatively rapidly growing developing economies. A simultaneity problem in equation (4) may also arise from the bi-directional relationship between the volume of international trade and the growth rate of real GDP. International trade will increase as economic growth expands the economy's export capacity. Thus, growth may influence trade as much as trade influences growth.

A common statistical approach to dealing with simultaneity bias is to use instrumental variables. It always remains a matter of speculation whether the particular instrumental variables chosen reduce the alleged biases or introduce new biases. We opt for the more direct approach of explicitly modeling the likely bi-directional relationships among the explanatory variables in equation (4) by specifying a simultaneous equations model (SEM). ${ }^{5}$ The statistical estimation of the coefficients of a SEM effectively uses the model's exogenous variables as instruments for estimating all coefficients, and it has the added benefit of permitting us to directly test the reverse relationships between variables.

To test the effect of FDI on U.S. economic growth, we specify the following four-equation simultaneous-equation model:

\footnotetext{
5 Sprout and Weaver (1993), Esfahani (1991), and Van den Berg (1996) acknowledged the potential for simultaneity bias by using SEMs to estimate the effect of trade on economic growth.
} 


$$
\begin{aligned}
& \operatorname{Gr}(\mathrm{Y})=\mathrm{a}_{\mathrm{o}}+\mathrm{a}_{1}(\mathrm{I} / \mathrm{Y})+\mathrm{a}_{2}(\mathrm{FDI} / \mathrm{Y})+\mathrm{a}_{3} \mathrm{Gr}(\mathrm{L})+\mathrm{a}_{4} \mathrm{Gr}(\mathrm{X})+\mathrm{t} \\
& \frac{\mathrm{FDI}}{\mathrm{Y}}=\mathrm{b}_{\mathrm{o}}+\mathrm{b}_{1} \mathrm{Gr}(\mathrm{Y})+\mathrm{b}_{2}(\mathrm{Y} / \mathrm{N})+\mathrm{b}_{3} \operatorname{Gr}\left(\mathrm{P}_{\mathrm{W}}\right)+\mathrm{t} \\
& \frac{\mathrm{I}}{\mathrm{Y}}=\mathrm{c}_{\mathrm{o}}+\mathrm{c}_{1} \mathrm{Gr}(\mathrm{Y} / \mathrm{N})+\mathrm{c}_{2}(\mathrm{Y} / \mathrm{N})+\mathrm{c}_{3} \mathrm{Gr}(\mathrm{X})+\mathrm{c}_{4} \mathrm{Gr}\left(\mathrm{K}_{\mathrm{f}}\right)+\mathrm{t} \\
& \mathrm{Gr}(\mathrm{X})=\mathrm{d}_{\mathrm{o}}+\mathrm{d}_{1} \mathrm{Gr}(\mathrm{Y})+\mathrm{d}_{2} \mathrm{RER}+\mathrm{d}_{3}(\mathrm{Y} / \mathrm{N})+\mathrm{d}_{4} \mathrm{Gr}\left(\mathrm{Y}_{\mathrm{f}}\right)+\mathrm{t}
\end{aligned}
$$

The first equation in the simultaneous-equation model (5) is equation (4) from above. The remaining equations in the model explain the first equation's explanatory variables. In addition to the variables introduced earlier, Y/N, RER and $\operatorname{Gr}\left(\mathrm{P}_{\mathrm{W}}\right)$ denote the real per capita GDP, the real effective exchange rate, and the growth rate of hourly wage index, respectively. $\operatorname{Gr}\left(\mathrm{K}_{\mathrm{f}}\right)$ is a measure of foreign capital flows, $\mathrm{N}$ is total population, $\operatorname{Gr}(\mathrm{Y} / \mathrm{N})$ and $\operatorname{Gr}\left(\mathrm{Y}_{\mathrm{f}}\right)$ are growth rates of real per capita GDP and a trade-weighted average real GDP per capita of major trading partners, respectively. We apply time-series data covering the period 1970-2001. The Data Appendix lists the data sources.

The time-series variables in model (5) may be non-stationary. Regression models including non-stationary independent variables are likely to generate "spurious" results, that is, conventional tests are biased toward finding a significant relationship among variables in levels when in fact none exists. ${ }^{6}$ The standard method for testing the stationarity of a time-series is to test for the presence or absence of a unit root. Testing is normally extended to account for a deterministic trend as well as the stochastic type of trend represented by a unit root. A number of tests can be found in Said and Dickey (1984), Kwiatkowski et. al (1992), Perron (1998), Phillips (1987) and Phillips and Perron (1988). We apply the tests of Phillips and Perron (PP), and Kwiatkowski et. al (KPSS) to detect the existence of unit roots in the variables in model (5). The former test assumes the null hypothesis of a unit root while the latter test assumes the null hypothesis of no unit root. Both tests are applied so that modeling directions are not inclined toward accepting one type of trend over the other.

Table 1 reports the unit root tests. PP and KPSS test results conform for all variables except I/Y, FDI/Y, Gr(L), RER, and $\operatorname{Gr}(\mathrm{X})$. Both PP and KPSS test results confirm the presence of a unit root in the series $\mathrm{Y} / \mathrm{N}$. PP test indicates unit roots in the variables I/Y, FDI/Y, Gr(L), RER, and $\operatorname{Gr}(\mathrm{X})$ while KPSS test did not detect the existence of unit roots. All other variables in the model are stationary according to both PP and KPSS tests. One common method of addressing the problem of unit roots in variables is to difference non-stationary variables prior to

\footnotetext{
6 Known as the spurious regression problem, it was popularized and studied extensively by Granger and Newbold (1974).
} 
the estimation of the model. We differenced all variables that are detected to have unit roots by either of PP or KPSS test. All differenced variables are found to be stationary. Therefore, all variables that are found to be non-stationary in levels will enter the model in their first differenced form. We added a time trend, $t$, in each equation to capture the effect of deterministic trend in level variables.

Table 1. Stationarity Test Results

\begin{tabular}{|c|c|c|}
\hline Variables & PP Test & KPSS Test \\
\hline $\operatorname{Gr}(Y)$ & $-4.3527^{*}$ & .0451 \\
\hline $\mathrm{I} / \mathrm{Y}$ & -3.0861 & .1003 \\
\hline FDI/Y & -2.4932 & .1034 \\
\hline $\operatorname{Gr}(\mathrm{L})$ & $-4.0439^{*}$ & .0704 \\
\hline $\mathrm{Y} / \mathrm{N}$ & -1.9508 & .1394 \\
\hline $\operatorname{Gr}\left(P_{\mathrm{W}}\right)$ & -2.6721 & .1033 \\
\hline RER & -2.2740 & .0716 \\
\hline $\operatorname{Gr}\left(Y_{f}\right)$ & $-4.0949^{*}$ & .0838 \\
\hline $\operatorname{Gr}(\mathrm{Y} / \mathrm{N})$ & $-4.3503^{*}$ & .0451 \\
\hline $\operatorname{Gr}\left(K_{f}\right)$ & $-3.7999^{*}$ & .0655 \\
\hline $\operatorname{Gr}(\mathrm{X})$ & -3.0877 & .0724 \\
\hline \multicolumn{3}{|c|}{$\begin{array}{l}\text { Notes: }{ }^{*} \text { - significant at the } 90 \text { percent level. The critical value for the PP test with } \\
\text { t and trend at the } 90 \text { percent level is }-3.132 . \text { The critical value for the KPSS test with } \\
t \text { and trend at the } 90 \text { percent level is } .119 \text {. }\end{array}$} \\
\hline
\end{tabular}

\section{ESTIMATION AND RESULTS}

We estimate model (5) using three stage least squares (3SLS). Table 2 reports the 3SLS estimates of the coefficients. In the first equation, the 3SLS estimate of the coefficient of FDI/Y is positive and significant at the 95 percent level. Both I/Y and $\operatorname{Gr}(\mathrm{X})$ are significant at the 95 percent level with the expected positive sign. $\operatorname{Gr}(\mathrm{L})$ has the expected positive but statistically insignificant coefficients. The important result is that the 3SLS estimate of the coefficient of FDI/Y confirms that FDI has enhanced U.S. economic growth. We conclude, 
therefore, that despite the evidence that U.S. technological progress has not been highly dependent on inflows of foreign investment, FDI nevertheless matters for U.S. economic growth. Comparing the coefficient for the FDI variable to the coefficient for other investment suggests that FDI is more important for growth than investment in general. This suggests that FDI does indeed involve greater technology flows than other forms of investment, foreign or domestic. The other coefficients are similar to those found in most other growth regressions using the sources of growth equation; namely, the labor force has an ambiguous effect on growth and foreign trade has a significant and positive effect on growth.

Table 2. Estimated Equations

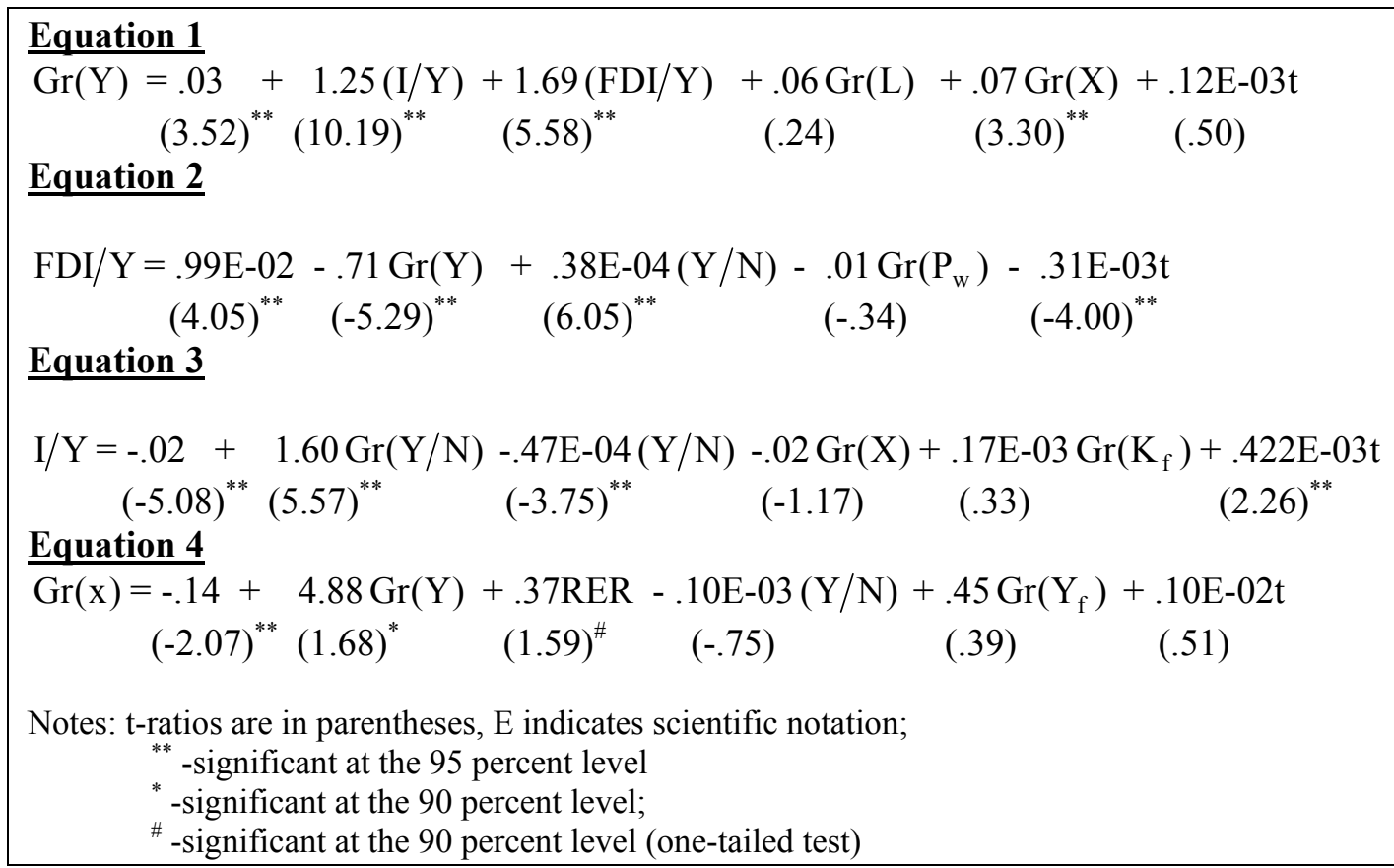

The estimate of the coefficient of $\operatorname{Gr}(\mathrm{Y})$ in the model's second equation, which explains FDI/Y, is negative and significant at the 95 percent level. The implication of this result is that the income elasticity of FDI/Y is less than one. The statistically significant coefficient of $\operatorname{Gr}(\mathrm{Y})$ confirms a bi-directional relationship between $\mathrm{Gr}(\mathrm{Y})$ and $\mathrm{FDI} / \mathrm{Y}$; our specification of a simultaneous equations model is therefore justified. Elsewhere in the equation, the coefficient of $\mathrm{Y} / \mathrm{N}$ is positive and significant at the 95 percent level. Thus, the signs and significance of the coefficients for $\mathrm{Y} / \mathrm{N}$ and $\operatorname{Gr}(\mathrm{Y})$ suggest that, ceteris paribus, 
Ghosh Roy and Van den Berg: Foreign Direct Investment and Economic Growth

higher-income countries attract more foreign direct investment, relative to GDP, than poorer countries, but FDI does not grow as fast as per capita income.

In the third equation, which explains the ratio of domestic investment to GDP, all variables except $\operatorname{Gr}(\mathrm{X})$ and $\operatorname{Gr}\left(\mathrm{K}_{\mathrm{f}}\right)$ are significant. The coefficient of $\mathrm{Gr}(\mathrm{Y} / \mathrm{N})$ is positive and significant at the 95 percent level. The negative coefficient of $\mathrm{Y} / \mathrm{N}$ is most likely the result of the income inelasticity of other investment, a very plausible explanation provided that the change in income still exceeds the change in population. All variables except $\mathrm{Y} / \mathrm{N}$ and $\operatorname{Gr}\left(\mathrm{Y}_{\mathrm{f}}\right)$ in the fourth equation explaining rate of growth of exports are significant with the expected signs. The coefficient of $\mathrm{Gr}(\mathrm{Y})$ is positive and significant at the 90 percent level. The positive and significant relationship shows that export growth and economic growth are interdependent. In accordance with trade theory, the estimated coefficient of RER is significant and positive. ${ }^{7}$

We conclude, therefore, that over the period 1970-2001, FDI had a positive effect on the growth of United States GDP. The simultaneous-equation model is clearly justified by the significant reverse relationships between the dependent and explanatory variables in the first equation of the model. Interestingly, the reverse relationship between the growth of GDP and the share of FDI relative to GDP in the second equation suggests that as the U.S. economy grows FDI will also grow, but not fast enough to maintain its share of U.S. GDP. This is an ominous result given the growth of the U.S. trade deficit in recent decades and the need for the U.S. to attract increasingly larger capital inflows to cover those growing deficits.

\section{SUMMARY AND CONCLUSIONS}

Given the current rapid growth and globalization of the world economy in general and the growth of international flows of foreign direct investment (FDI) in particular, it is important to understand the relationship between FDI and economic growth. The uneven growth of FDI and the lack of a consensus on the precise role of FDI in the global economy underscore the need to get a better handle on precisely how FDI affects economic welfare. Much research has focused on the role of FDI in transferring leading technology from developed to developing economies. This article recognizes that most FDI moves between

7 The coefficient estimate of RER is significant using one-tailed test. However, use of a one-tailed test is appropriate here; RER is stated in U.S. dollars, and as long as the MarshallLerner condition is satisfied, a depreciation of the dollar (increase in RER) must have a positive effect on the value of exports. 
developed countries and that, in recent years, the United States has been the largest recipient of FDI. An examination of how inflows of FDI to the United States have affected U.S. economic growth is also called for because the long-run consequences of FDI inflows for U.S. economic growth are theoretically ambiguous. FDI's role in transferring technology may not be important for a technological leader like the United States. On the other hand, there is evidence that most economies depend on inflows of foreign technology for most of their technological progress.

The relationship between FDI and economic growth is inherently complex. The likelihood of simultaneous relationships among the variables in a simple regression equation makes traditional statistical estimation of the relationship between FDI and growth problematic. The most direct way to deal with the bi-directional nature of the relationships between growth and FDI, other forms of investment, and trade (exports) is to specify the potential bi-directional relationships explicitly in a simultaneous-equation model. We develop a simultaneous equation model to capture the bi-directional relationship between the share of FDI in GDP and economic growth. The model is estimated using time-series data covering the period 1970-2001 and adjusting the variables in accordance with two unit root tests.

The effect of FDI/Y on economic growth is found to be positive, and statistically significant. Thus, the expansion of FDI has contributed to U.S. economic growth and long-run welfare over the period 1970-2001. The regression results also suggest that it may not be possible to maintain the recent rapid growth of FDI relative to GDP, however. The negative coefficient for the growth of GDP in the equation for FDI/Y implies that the elasticity of FDI to GDP is less than one.

From a macroeconomic perspective, these statistical results are intriguing. If FDI continues to raise the U.S. rate of economic growth, the potentially adverse consequences of government budget deficits and the demographic effects on pension and social security liabilities would be mitigated. Faster economic growth both raises long-run human welfare and expands the country's options for dealing with a variety of economic issues in the future.

Whether FDI increases U.S. technological progress and whether FDI will continue to grow as rapidly as it has over the past several decades are also important questions in the current debate about the "sustainability" of the United States' growing current account deficits. If inflows of foreign direct investment continue to raise the U.S. rate of technological progress, then the trade deficit poses less of a long-run burden, all other things equal, than if FDI has no growth effect. On the other hand, the finding that FDI does not grow in proportion to GDP means that the U.S. economy cannot count on economic growth to continue expanding capital inflows to offset its growing current account deficits. 
Ghosh Roy and Van den Berg: Foreign Direct Investment and Economic Growth

While no one econometric study provides definitive proof of a relationship, our results present a suggestive picture of how the U.S. economy is influenced by FDI. The inflows of FDI have been beneficial for the U.S. economy. Policies to keep the United States attractive to foreign direct investment are clearly called for. However, given the income inelasticity of FDI inflows, they cannot be counted on to cover the U.S.'s growing current account deficits in the future.

\section{Appendix : Variable List and Data Sources}

\section{A.1 Variable List}

Y: Real Gross Domestic Product

$\mathrm{Gr}(\mathrm{Y})$ : Growth Rate of Real gross domestic product

I: Domestic investment minus FDI

I/Y : Ratio of domestic investment minus FDI to gross domestic product

FDI/Y : Ratio of FDI to gross domestic product

L: Labor Force

$\mathrm{X}$ : Real Export

Gr(X): Growth Rate of Real Exports

N: Population

Y/N : Per Capita Real GDP

$\mathrm{Gr}\left(\mathrm{P}_{\mathrm{W}}\right)$ : Growth Rate of Real Wage Rate

$\operatorname{Gr}\left(\mathrm{Y}_{\mathrm{f}}\right)$ :Trade Weighted Average Real GDP Per Capita of Major Trading Partners

(Canada, France, Italy, United Kingdom, Mexico)

RER: Real Effective Exchange Rate (in U.S. dollars)

$\mathrm{K}_{\mathrm{f}}$ : Real Foreign Capital Inflows measured by real export minus real import plus real net foreign factor income earned abroad.

$\operatorname{Gr}\left(\mathrm{K}_{\mathrm{f}}\right)$ : Growth Rate of Real Foreign Capital Inflows

\section{A.2 Data Sources}

Y: Bureau of the Economic Analysis (BEA)

Gr(Y): Derived

$\mathrm{X}, \mathrm{N}$ : International Monetary Fund, International Financial Statistics, CD-ROM version, March, 2004.

$\mathrm{Y} / \mathrm{N}$ : Derived

$\operatorname{Gr}(\mathrm{Y} / \mathrm{N})$ : Derived

L: U.S. Government Printing Office (2003), Economic Report of the President. 
Gr(L): Derived

I, FDI: World Bank, World Development Indicators, CD-ROM, 2005

$\mathrm{I} / \mathrm{Y}:$ Derived

FDI/Y : Derived

$\mathrm{Gr}\left(\mathrm{P}_{\mathrm{W}}\right)$ : International Monetary Fund, International Financial Statistics, CD-ROM version, March, 2004.

RER: Trade weighted real effective exchange rate. Exchange rates of major trading partners (Canada, France, Italy, United Kingdom, Japan and Mexico) and the United States are from Alan Heston, Robert Summers, and Bettina Aten Pen world table version 6.1 and United Nations Economic Commission for Europe (UNECE). Trade weights are from the U.S. Bureau of the Census. Consumer Price Indices of the United States and major trading partners are from the International Financial Statistics, CD-ROM version, March 2004.

$\operatorname{Gr}\left(\mathrm{Y}_{\mathrm{f}}\right)$ : Computed by calculating trade weighted growth rate of real GDP of major trading partners (Canada, France, Italy, United Kingdom, Japan and Mexico). The data source of real GDP of trading partners is Angus Maddison. 2003. The World Economy: Historical Statistics. Paris, OECD.

$\mathrm{K}_{\mathrm{F}}$ : calculated by subtracting import from export and adding net foreign factor income from abroad. The data source for net foreign factor income abroad is International Financial Statistics, CD-ROM version, March 2004.

\section{REFERENCES}

Abramovitz, Moses. 1986. Catching Up, Forging Ahead, and Falling Behind. Journal of Economic History. 46(2): 385-406.

Acemoglu, Daron, Zilibotti, Fabrizio. 2001. Productivity Differences. Quarterly Journal of Economics. 116(2): 563-606.

Aitken, Brian J., Harrison, Ann E.. 1999. Do Domestic Firms Benefit from Direct Foreign Investment? Evidence from Venezuela. American Economic Review, 89(3): 605-618.

Balasubramanyam, Venkataraman N., Salisu, Mohammed A., Sapsford, David. 1996. Foreign Direct Investment and Growth in EP and IS Countries. Economic Journal. 106: 92-105.

Balasubramanyam, Venkataraman N., Salisu, Mohammed A., Sapsford, David. 1999. Foreign Direct Investment as an engine of Growth. The Journal of International Trade \& Economic Development. 8: 27-40. 
Ghosh Roy and Van den Berg: Foreign Direct Investment and Economic Growth

Baldwin, Robert E. 2003. Openness and Growth: What's the Empirical Relationship? in Challenges to Globalization, ed. Robert E. Baldwin and L. Alan Winters, Chicago: University of Chicago Press.

Basu, Susanto, Weil, David N. 1998. Appropriate Technology and Growth. Quarterly Journal of Economics. 108(4): 1025-1054

Bekaert, Geert, Harvey, Campbell R. 2000. Foreign Speculators and Emerging Equity Markets. The Journal of Finance. 55(2): 565-613.

Bernstein, Jeffrey I. 1996. International R\&D Spillovers between Industries in Canada and the United States, Social Rates of Return and Productivity Growth. Canadian Journal of Economics. 29(2): 463-467.

Bernstein, Jeffrey I., Mohnen, Pierre. 1998. International R\&D Spillovers between U.S. and Japanese R\&D Intensive Sectors. Journal of International Economics. 44(2): 315-338.

Blomström, Magnus, Kokko, Ari. 1998. Multinational Corporations and Spillovers. Journal of Economic Surveys. 12(2): 1-31.

Borensztein, E., De Gregorio, J., Lee, J.W. 1998. How Does Foreign Direct Investment Affect Economic Growth? Journal of International Economics. 45: 115-135.

Branstetter, Lee. 2000. Is Foreign Direct Investment a Channel of Knowledge Spillovers? Evidence from Japan's FDI in the United States. NBER Working Paper No. 8015.

Caselli, Fracesco. 2004. Accounting for Cross-Country Income Differences, NBER Working Paper No. 10828

Caves, Richard E. 1996. Multinational Enterprise and Economic Analysis, Cambridge: Cambridge University Press.

Coe, David T., Helpman, Elhana. 1995. International R\&D Spillovers. European Economic Review. 39: 859-87.

Coe, David T., Helpman, Elhana, Hoffmaister, Alexander W. 1997. North-South R\&D Spillovers. Economic Journal. 107: 134-149. 
Conolly, Michelle. 2000. North-South Technological Diffusion; A New Case for Dynamic Gains from Trade. Duke University Economics Department Working Paper \# 99-08.

Djankov, Simeon, Hoekman, Bernard. 2000. Foreign Investment and Productivity Growth in Czech Enterprises. World Bank Economic Review. 14(1): 49-64.

Easterly, William, Levine, Ross. 2001. It's Not Factor Accumulation: Stylized Facts and Growth Models. The World Bank Economic Review. 15(2): 177-219.

Eaton, Jonathan, Kortum, Samuel. 1996. Trade in Ideas, Patenting and Productivity in the OECD. Journal of International Economics. 40(3): 251-278.

Edwards, Sebastian. 1993. Openness, Trade Liberalization, and Growth in Developing Countries. Journal of Economic Literature. 31: 1358-1393.

Edwards, Sebastian. 1998. Openness, Productivity and Growth: What Do We Really Know?. The Economic Journal. 108: 383-398.

Esfahani, Hadi S. 1991. Exports, Imports, and Economic Growth in SemiIndustrialized Countries. Journal of Development Economics. 35: 93-116.

Evenson, Robert E., Singh, Lakhwinder. 1997. Economic Growth, International Technology Spillovers and Public Policy: Theory and Empirical Evidence from Asia. Economic Growth Center, Yale University, Discussion Paper No. 777.

Glaeser, Edward, Kallal, H.D., Scheinkman, José A., Schleifer, Andre. 1991. Growth in Cities. NBER Working Paper, No. 3787, July.

Granger, C. W. J., Newbold, P. 1974. Spurious Regressions in Economics. Journal of Econometrics. 4: 205-210.

Griliches, Zvi. 1998. R\&D and Productivity, Chicago: University of Chicago Press.

Haddad, Mona, Harrison, Ann E. 1993. Are there Positive Spillovers from Direct Foreign Investment? Evidence from Panel Data for Morocco. Journal of Development Economics. 42(1): 51-74.

Hajeazi, Walid, Safarian, A. Edward. 1999. Trade, Foreign Direct Investment, and R\&D Spillovers. Journal of International Business Studies. 30(3): 491-512. 
Ghosh Roy and Van den Berg: Foreign Direct Investment and Economic Growth

Haskel, Jonathan E., Sonia C. Pereira, Slaughter, Matthew J. 2002. Does Inward Foreign Direct Investment Boost the Productivity of Domestic Firms?. NBER Working Paper \# 8724.

Keller, Wolfgang. 1996. Absorptive Capacity: On the Creation and Acquisition of Technology in Development. Journal of Development Economics. 49(1): 199227.

Keller, Wolfgang. 2001. The Geography and Channels of Diffusion at the World's Technology Frontier. NBER Working Paper \# 8150.

Keller, Wolfgang. 2002. Geographic Localization of International Technology Diffusion. American Economic Review. 92(1): 120-142.

Keller, Wolfgang, Yeaple, Stephen R. 2003. Multinational enterprises, International Trade, and Productivity Growth: Firm-Level Evidence from the United States. NBER Working Paper \# 9504.

Konings, Josef. 2001. The Effects of Foreign Direct Investment on Domestic Firms. Economics of Transition. 9(3): 619-633.

Kwiatkowski, Denis, Phillips, Peter C.B., Schmidt, Peter, Shin, Yongcheol. 1992. Testing the Null Hypothesis of Stationarity against the Alternative of a Unit Root. Journal of Econometrics. 54: 159-78.

Lewer, Joshua J., Van den Berg, Hendrik. 2003. How Large is International Trade's Effect on Economic Growth? Journal of Economic Surveys. 17(3): 363396.

Mayer, Jörg. 2001. Technology Diffusion, Human Capital and Economic Growth in Developing Countries. United Nations Conference in Trade and Development Discussion Paper, No. 154, June.

Moran, Theodore H. 1998. Foreign Direct Investment and Development. Washington, D.C.: Institute for International Economics.

Most, Steven, Van den Berg, Hendrik. 1996. Growth in Africa: Does the Source of Investment Financing Matter? Applied Economics. 28: 1427-1433.

Patillo, Catherine, Hélène Poirson, Ricci, Luca. 2002. External Debt and Growth. IMF Working Paper WP/02/69; www.imf.org. 
Perron, P. 1988. Trends and Random Walks in Macroeconomic Time Series: Further Evidence from a New Approach. Journal of Economic Dynamics and Control. 12: 297-332.

Phillips, P.C.B. 1987. Time Series Regression with a Unit Root. Econometrica. 55: 277-301.

Phillips, P.C.B., Perron, P. 1988. Testing for a Unit Root in Time Series Regression. Biometrika. 75: 335-46.

Rashid, Aneesa I. 1995. Trade, Growth, and Liberalization: The Indian Experience, 1977-1989. Journal of Developing Areas. 29: 355-370.

Rodriguez, Francisco, Rodrik, Dani. 2001. Trade Policy and Economic Growth: A Skeptics Guide to the Cross-National Evidence. in NBER Macroeconomics Annual 2000, ed. Ben Bernanke, and Kenneth S. Rogoff, Cambridge, MA: MIT Press.

Rodrik, Dani. 1992. Closing the Productivity Gap: Does Trade Liberalization Help? in Trade Policy, Industrialization, and Development: New Perspectives, ed. G.K. Helleiner, pp. 155-175. Oxford: WIDER Studies in Development Economics, Clarendon Press.

Rodrik, Dani. 1999. The New Global Economy and Developing Countries: Making Openness Work. Overseas Development Council (Baltimore, MD) Policy Essay No. 24.

Rodrik, Dani, Subramanian, Arvind, Trebbi, Francesco. 2002. Institutions Rule: The Primacy of Institutions over Geography and Integration in Economic Development. NBER Working Paper No. w9305.

Romer, Paul M. 1993. Idea Gaps and Object Gaps in Economic Development. Journal of Monetary Economics, 32: 543-573.

Said, S.E., Dickey, D.A. 1984. Testing for Unit Roots in Autoregressive-Moving Average Models of Unknown Order. Biometrica. 71: 599-608.

Smarzynska, Beata K. 2000. Technological Leadership and Foreign Investors Choice of Entry Mode. World Bank Research Paper No. 2314. 
Ghosh Roy and Van den Berg: Foreign Direct Investment and Economic Growth

Solow, Robert M. 1956. A Contribution to the Theory of Economic Growth. Quarterly Journal of Economics. 70(1): 65-94.

Sprout, Ronald V.A., Weaver, James H. 1993. Exports and Economic Growth in a Simultaneous Equations Model. Journal of Developing Areas. 28(4): 289-306.

Van den Berg, Hendrik. 1996. Trade as the Engine of Growth in Asia: What the Econometric Evidence Reveals. Journal of Economic Integration. 11: 510-538.

Van den Berg, Hendrik, Schmidt, James R. 1994. Foreign Trade and Economic Growth: Time Series Evidence from Latin America. The Journal of International Trade and Economic Development. 27: 249-268. 